\title{
高層建築物の屋上目隠しパネルに作用する風力 \\ WIND FORCES ON POROUS PANELS PLACED ALONG THE PERIMETER OF THE ROOFTOP OF HIGH-RISE BUILDING
}

\author{
相原 知子*, 植松 康** \\ Tomoko AIHARA and Yasushi UEMATSU
}

\begin{abstract}
Blind panels are often attached to the roof of a building along its perimeter to keep outdoor equipment from sight. Permeable materials are generally used in order to cool the equipment by winds. Furthermore, it is expected that the wind loads on such panels are smaller than those on solid panels. Previous studies of wind loads on blind panels focused on solid panels. Few studies have been made of permeable panels.

The present paper investigates the wind force coefficients on solid and permeable blind panels installed on the roof of a high-rise building based on a wind tunnel experiment and a CFD simulation with LES, in which the porosity is changed from 0 to $80 \%$. In the wind tunnel experiment, the wind pressure coefficients on the roof near the panel are used for those on the panel's interior surface for calculating the net wind force coefficients. Such a wind tunnel technique is verified by the numerical results. Furthermore, the simulated results indicate that large positive wind forces are induced in the upper part of solid panel, the mechanism of which is discussed based on the visualization of the flow around the panel. The effect of porosity on the wind force coefficients on permeable blind panels is also discussed.
\end{abstract}

Keywords: CFD, LES, Wind tunnel experiment, Permeable panel, Rooftop, Wind force CFD, LES, 風洞実験, 通気性パネル, 屋上, 風力

\section{1. はじめに}

建築物の屋上外周部には, 設備機器等の目隠しのためのパネルが 設置されている場合が多い。しかし，屋上目隠しパネル（目隠し壁 やパラペット，冠壁とも呼ばれている）の風荷重は，建設省告示第 1458 号や日本建築学会の建築物荷重指針 1)には定められていない。 屋上目隠しパネルの風力係数については, 日本建築学会の「実務者 のための建築物外装材耐風設計マニュアル 2)」に示されている他, 既存の研究報告が参考となる。例えば, Stathopoulos らは, 建築物の 幅と建築物の高さの比率が 1:1 2:1 の建築物を対象とし, 屋上目 隠しパネルの高さをパラメータとした風圧実験によりパネル近傍の 屋根面圧とパネルの裏面圧の比較を行っている ${ }^{3)}$ 。大竹は, 大規模 工場を想定した高さ $30 \mathrm{~m}$ と $45 \mathrm{~m}$ の建築物を対象として, 目隠しパ ネルの高さをパラメータとした風圧実験を実施しており，目隠しパ ネルの高さが $7.5 \mathrm{~m}$ の場合，上部と下部で目隠しパネルのピーク風 力係数に大きな違いは見られなかったとしている ${ }^{4)}$ 。本田らは, 高 さ $45 \mathrm{~m}$, アスペクト比（建築物の高さ／建築物の幅） 3 の建築物（正 方形平面）を対象として，建築物端部から目隠しパネルまでの離隔 距離をパラメータとした風圧実験を実施しており, 目隠しパネルの ピーク風力係数は最大で 3.9 程度であったとしている ${ }^{5)}$ 。田川らは,
高さ $40 \mathrm{~m} \sim 200 \mathrm{~m}$ の中高層建築物を対象とし，建築物のアスペクト 比（建築物の高さ／建築物の短辺側の幅）と辺長比ならびに屋上目 隠しパネルの高さをパラメータとした風圧実験を実施しており，ア スペクト比が 1 と 2 の場合, 隅角部ほど大きな風力が作用し, 風力 係数の絶対值の最大值は, 正の風力係数（目隠しパネルを外側から 屋根面側に押寸方向）で 5.5 程度であった。一方，アスペクト比 3〜 5 の場合における風力係数の最大值および最小值は，隅角部におい て 4 程度および-4.5 程度であった ${ }^{6)}$ 。伊藤らは，耐風設計に対する 数值流体解析の適用性を検討することを目的として，高さ $128 \mathrm{~m} の$ 高層建築物を対象とした風圧実験結果を報告しており，目隠しパネ ルのピーク風力係数の絶対值の最大值は 3 程度であった ${ }^{7)}$ 。

これらの研究においては, いずれも通気性のない開口率 $0 \%$ のパ ネルを対象としている。しかし, 設備機器の温度上昇を防ぐために, ルーバーやパンチングメタルなど通気性のある材料が用いられる場 合も多い。それにもかかわらず，通気性のある屋上目隠しパネルの 風力係数に関する資料は少ない。服部らは, 通気性のある屋上目隠 しパネルが屋根面に作用寸る風圧に与える影響について報告してい るが，パネルに作用する風力については述べられていない ${ }^{8)}$ 。筆者 らは, 高さ $90 \mathrm{~m}$ の高層建築物の屋上目隠しパネルを対象として, 通
* 大成建設(株技術センター 副主查研究員

** 東北大学大学院工学研究科都市. 建築学専攻 教授. 工博
Research Engineer, Technology Center, TAISEI CORPORATION

Prof., Dept. Architecture and Building Science, Graduate School of Engineering,

Tohoku University, Dr.Eng. 
気性のない開口率 0\%の他に，通気性のある開口率 20\%，50\%，80\% の金属プレートを模型化材料として使用した風圧実験を実施し，高 層建築物の屋上外周部に設置されている通気性のある目隠しパネル に作用する風荷重について報告した 9)。風圧実験で屋上目隠しパネ ルの表面圧および裏面圧を測定する場合, 開口率 $0 \%$ のパネルであ れば，文献 3）～6）のように，風圧測定孔に繋がる金属タップおよび ビニールチューブ (導圧管) をパネルの中に内蔵させることでそれ らが表に露出することを防ぐことが可能となるが，通気性のある金 属プレートを目隠しパネルの模型化材料として用いる場合, 導圧管 を内蔵させることはできない。文献 9)では, パネルの裏面圧の代わ りに測定孔を配置しや寸い（導圧管が露出しない) パネル近傍の屋 根面圧を測定し，パネルの表面圧との差からパネルの風力係数を求 めている。なお, 文献 7)においても, パネルの風力係数を, パネル の表面圧とその位置に近い屋根面圧の差から求めている。さらに, 筆者らは，パネルの裏面圧の代わりに屋根面圧を用いる風圧実験手 法の妥当性を検討することを目的とし，文献 9)の風圧実験と同じモ デル（ただし，開口率 0\%と 20\%のみ）を対象として, Large Eddy Simulation (LES) に基づく数值流体計算 (CFD) を実施し, パネル表面 圧の風圧測定孔に繫がる導圧管の露出がパネルに作用寸る風圧に及 ぼす影響やパネル裏面圧としてパネル近傍の屋根面圧を代用してパ ネルに作用する風力を推定する手法の妥当性について報告している 10)。文献 10)では，CFD で得られたパネルの外圧係数および風力係 数を文献 9)の風洞実験結果と比較することで精度検証を行い，開口 率 $20 \%$ の屋上目隠しパネルの場合，パネルの裹面圧として，パネル の中央高さ（模型寸法で，屋根面から $10 \mathrm{~mm}$ ）における裏面圧を用 いても，近傍の屋根面圧（模型寸法で，建築物端部から $5 \mathrm{~mm}$ )を用 いても, 得られた風力係数は同程度であることが示された。しかし， 開口率 $0 \%$ の場合, 風向によっては, パネルの裏面圧が高さ方向に分 布をもち，パネルの風力係数が上層ほど大きくなるため，パネルの 裏面圧として屋根面圧を代用すると風荷重を過小評価する可能性を 示した。

本論文では，上記過小評価の原因となっている, 開口率 $0 \%$ の屋上 目隠しパネルにおいて，風下側のパネル上層部に発生する強い負圧 の発生メカニズムについて検討すると共に，新たに開口率 50\%のケ 一スについて CFD を実施したので，開口率 20\%の屋上目隠しパネ ルに関する結果との差異について報告する。なお，本検討ではパン チングメタルのようなプレート状の通気性材料を対象とする。

\section{2. 風洞実験概要}

\section{1 建物モデル}

Fig.1 に実験模型の寸法を示寸。幅 $B=100 \mathrm{~mm}$, 奥行 $D=100 \mathrm{~mm}$, 高 さ $\mathrm{H}=300 \mathrm{~mm}$ であり，屋上目隠しパネルの高さ $\mathrm{h}$ は $20 \mathrm{~mm}$ である。

風圧実験結果について報告した文献 9)では, 屋上目隠しパネルの 模型化材料として，開口率 0\%および開口部の寸法 W（Table 1 中の 図参照) $1 \mathrm{~mm}, 2 \mathrm{~mm}, 3 \mathrm{~mm}$ と固定し, 線材の幅 $\mathrm{d}$ (Table 1 中の図 参照）を変化させることで開口率を $20 \%, 50 \%, 80 \%$ とした合計 9 種 類（開口率 $80 \%$ の $\mathrm{W}=1 \mathrm{~mm}$ は除く）の金属プレートを用いている。 本検討では，開口率 0\%，20\%および50\%（いずれもW=3mm）の屋 上目隠しパネルを対象とする。Table1 に本検討で対象とする通気性 材料の概要を示す。圧力損失係数らは, 電動送風機, オリフィス流量
計, 圧力損失係数測定部を内径 $12.5 \mathrm{~cm}$ の塩ビ管で連結した圧力損 失係数測定装置 ${ }^{11)}$ 用いて測定した金属プレート前後の差圧を管内 平均速度圧で除した值である。なお，通気性材料である金属プレー

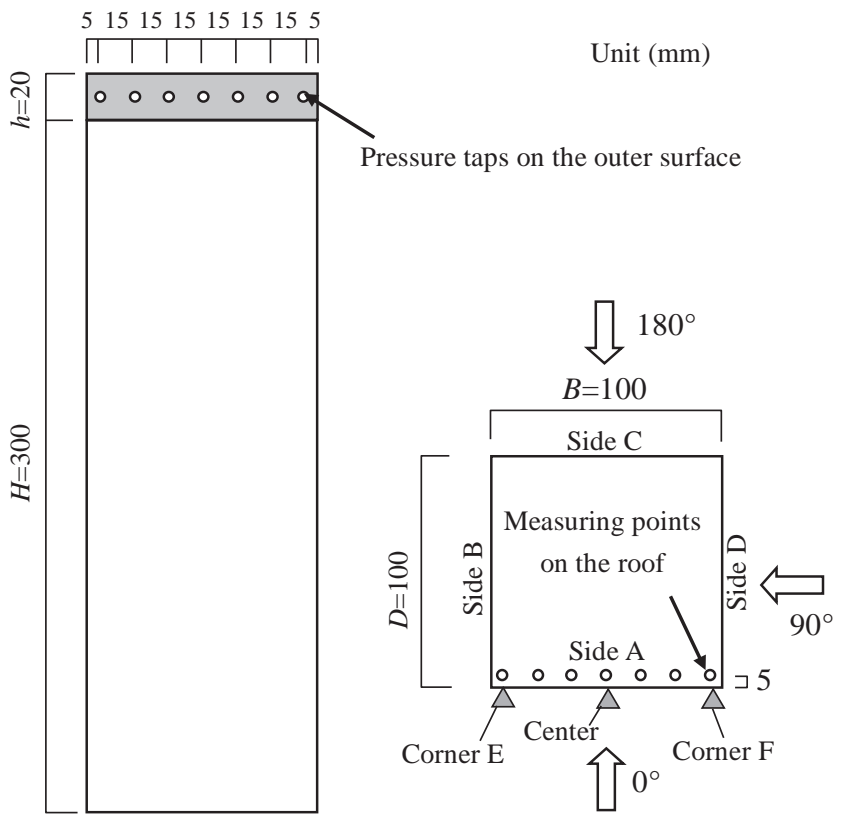

(a) Side view

(b) Top view

Fig. 1 Details of the experimental model and definition of wind direction

Table 1 Parameters of permeable materials

\begin{tabular}{|c|c|c|}
\hline $\begin{array}{c}\text { Porosity (\%) } \\
\text { W (mm) }\end{array}$ & 20 & 50 \\
\hline $\begin{array}{c}\text { Opening pitch } \\
\text { P (mm) }\end{array}$ & 3.0 & 3.0 \\
\hline $\begin{array}{c}\text { W ire width } \\
\text { d (mm) }\end{array}$ & 3.71 & 4.24 \\
\hline $\begin{array}{c}\text { Plate thickness } \\
\text { t (mm) }\end{array}$ & 0.2 & 0.2 \\
\hline Pressure loss coefficient $\zeta$ & 44.0 & 4.0 \\
\hline
\end{tabular}

Unit (mm) - M easuring points (Only side A)

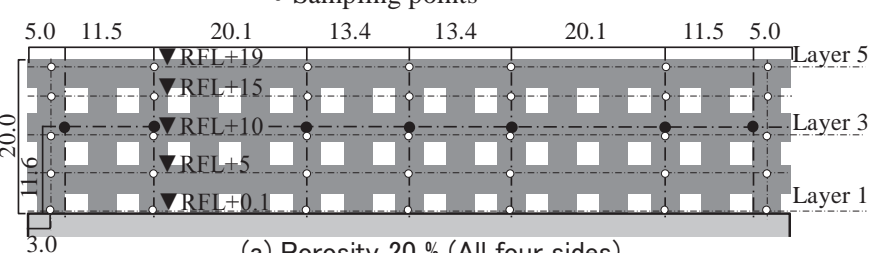

(a) Porosity 20 \% (All four sides)

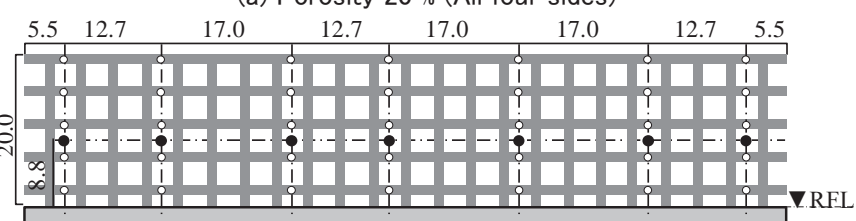

(b) Porosity 50 \% (Side A and side C)

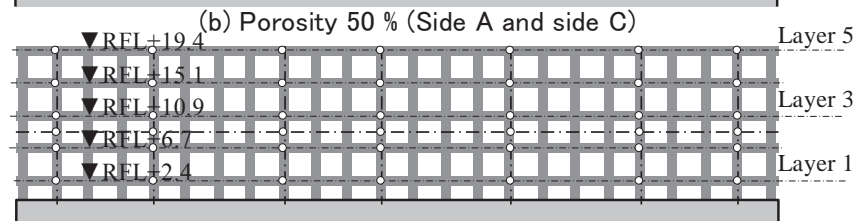

(c) Porosity 50 \% (Side B and side D)

Fig. 2 Location of measuring points (experiment) and sampling points (CFD) 
トは, エッチング加工により孔を設けた厚さ $0.2 \mathrm{~mm}$ の真鍮板である。 屋上目隠しパネルの表面圧を測定するための風圧測定孔は，A 面 (Fig.1(b) 参照)にのみ, 屋根面から約 10mm の高さ (パネルのほぼ中 央高さ）に 7 点配置されている。開口率 $0 \%$ のパネルの表面圧測定 点はFig.1(a) に示す通りである。開口率 20\%および50\%の場合の表

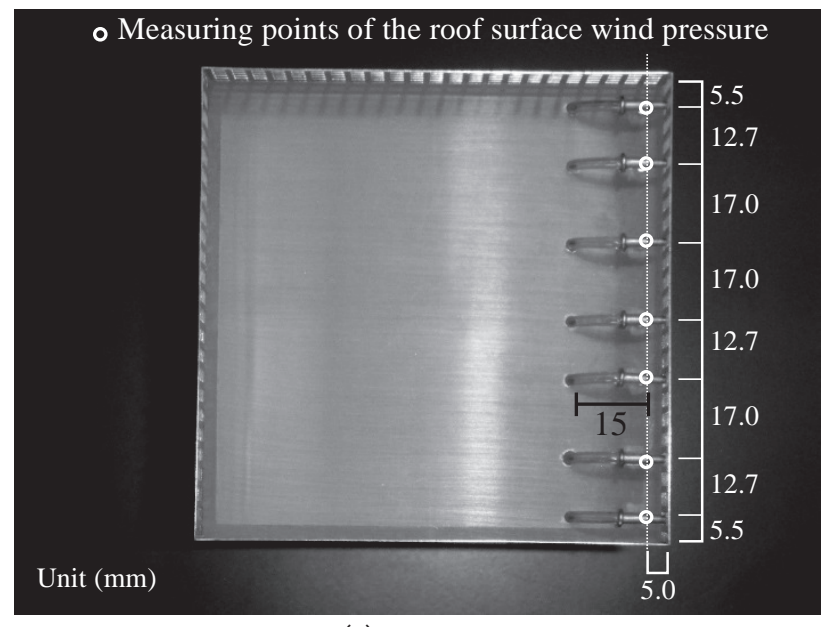

(a) Top view

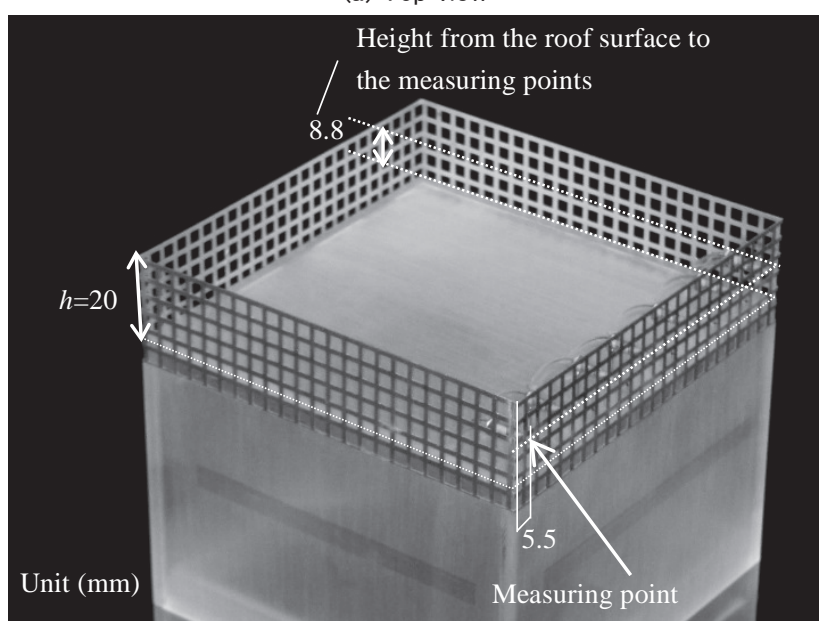

(b) Diagonal top view

Photo 1 Experimental model (porosity 50 \%)
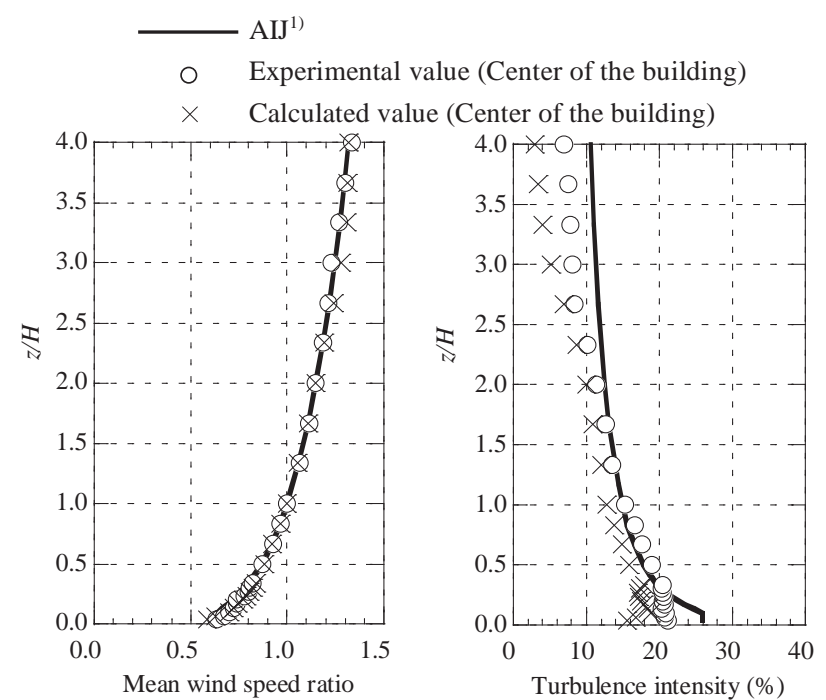

Fig. 3 Vertical profiles of mean velocity and turbulence intensity
面圧測定点位置を通気性材料の開口部の配置図と共に Fig.2 (a)，(b) に示す。通気性のあるパネルの表面圧測定点位置は, 線材の寸法 d (Table 1 参照) が大きい開口率 $20 \%$ の通気性材料を用いたケースで は, 通気性材料の線材中央に設け, 開口率 $50 \%$ および $80 \%$ では d が 小さいため, 線材中央ではなく開口部中央等に設けた。例として, 開口率 $50 \%$ の実験模型写真をP Photo 1 に示す。圧力測定点位置はこ の写真に示寸通りであり, 開口率 $0 \%$ の場合の測定点位置になるべ く近い位置に設けられている。屋上目隠しパネルの表面圧測定用チ ユーブは, 屋上面に設けた風圧測定孔から $15 \mathrm{~mm}$ 程度離れた場所か ら模型内部へと引き込まれている。

パネルの裏面圧として代用する屋根面圧の測定孔は, 表面圧測定 孔を配置した $\mathrm{A}$ 面の目隠しパネルから $5 \mathrm{~mm}$ 離れた位置に 7 点配置 した (Fig.1(b)およびPhoto 1 (a) 参照)。

\section{2 実験条件およびデータ処理方法}

風圧実験は大成建設 (株) 技術センター所有のエッフェル型境界層 風洞を用いて行った。実験気流は縮尺率を $1 / 300$ とし, 建築物荷重 指針 ${ }^{1)}$ に定められている地表面粗度区分IIIに概ね相当寸る境界層乱 流である（Fig.3 の○）。高さH（風洞床上 $300 \mathrm{~mm} ）$ における乱れの 強さ $I_{H}$ は $15.3 \%$, 乱れのスケール $\mathrm{L}_{\mathrm{x}}$ は $43.4 \mathrm{~cm}$ である。

実験風向は, Fig.1 (b)に示寸 $0^{\circ}$ から $180^{\circ}$ まで，上から見て反時計

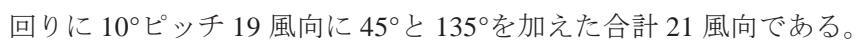

高さH（風洞床上 $300 \mathrm{~mm}$ ）における実験風速 $U_{H}$ は約 $13.5 \mathrm{~m} / \mathrm{s}$ で あり, 風速の縮尺率は約 $1 / 3$ を想定している。Fig.4には, 風速のパ ワースペクトル密度 S(f)を文献 1) で用いられているカルマン型のパ ワースペクトルと共に示す。開口部の寸法 W (Table 1 中の図参照) を代表長さ， $U_{H}$ を代表速度とし，空気の動粘性係数 $v$ を $1.5 \times 10^{-5}$ $\left(\mathrm{m}^{2} / \mathrm{s}\right)$ とすると, レイノルズ数 Re $\left(=\mathrm{U}_{H} \mathrm{~W} / \mathrm{v}\right)$ は $2.7 \times 10^{3}$ である。

模型に作用する風圧は, サンプリング間隔を 0.001 秒とし, 実大 約 50 分間相当（データ個数 32,768 個）の測定を行った。導圧管に おいて生じる共振現象（Helmholtz 共振）等による風圧の歪みは, 導 圧管の周波数応答特性をあらかじめ調べ，風圧測定後に補正した。 外圧係数と風力係数は, 模型を設置していない状態で測定したター ンテーブル中心（模型を設置した状態では模型中心となる位置）の 高さH における速度圧を用いて定義した。外圧係数は面を押寸向き が正，風力係数はパネルを表側から屋根側に押す向きが正である。 ピーク值は, 平均化時間を実大相当 0.5 秒とし, 評価時間 10 分間相 当で 5 回の結果のアンサンブル平均により評価した。

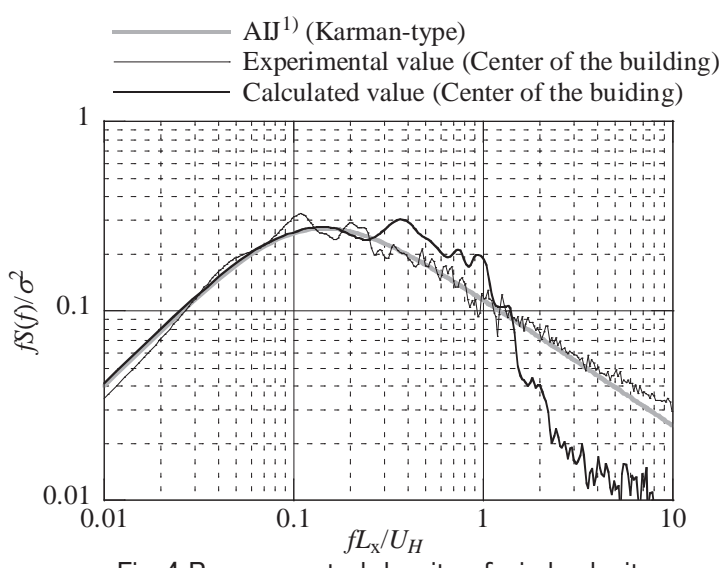

Fig. 4 Power spectral density of wind velocity 


\section{3. 数値流体解析概要}

計算対象は，開口率 0\%, 20\%および 50\%の屋上目隠しパネルを有 する風洞実験モデルであり，開口部の寸法 W, P , d (Table 1 中の図 参照）および Fig.2 に示寸開口部の配置を一致させている。解析用 モデルをFig.5 に示す。

支配方程式は非圧縮性の N avier-Stokes 方程式および連続の式であ る。離散化手法はFinite Volume M ethod (FVM), 乱流モデルは LES であり, Subgrid-scale (SGS) モデルには標準 Smagorinsky モデルを使 用し，モデル定数 CS は 0.15 とする。計算格子は四面体（テトラ） 要素を主とする非構造格子である。

風向は，風洞実験において最大および最小のピーク風力係数が発 生した風向を参考にして，開口率が $20 \%$ と $50 \%$ の場合は $0^{\circ}$ （壁面に 正対する風向）と $45^{\circ}$ （対角線方向）の 2 風向，開口率が $0 \%$ の場合 は $0^{\circ}, 45^{\circ}, 70^{\circ}$ の 3 風向である。風洞実験では, Fig.1(b)に示す ように $\mathrm{A}$ 面にのみ風圧測定孔が設けられていたが, 数值流体解析て は, パネル 4 面において風洞実験模型の $A$ 面の風圧測定孔と同じ位 置の風圧をサンプリングする。ただし，開口率 50\%の場合, Fig.2 (b)

に○印で示すように，実験模型ではパネルの表面圧測定孔がパネル の開口部に設けられているが，解析用モデルでは導圧管を再現して いないため，同じ位置でサンプリングしたデータを用いても風圧実 験結果と直接比較することができない。C 面についても $\mathrm{A}$ 面と同様 である (Fig.2 (b) 参照)。そこで，A 面およびC 面については測定孔 （屋根面から模型寸法で $8.8 \mathrm{~mm}$ の高さ）の上下の横方向に連続する

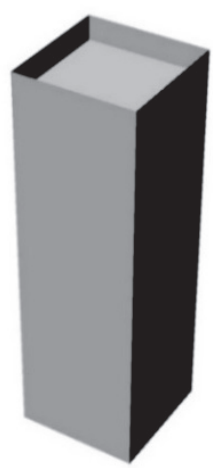

(a) Porosity $0 \%$

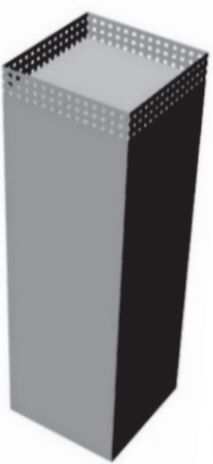

(b) Porosity $20 \%$

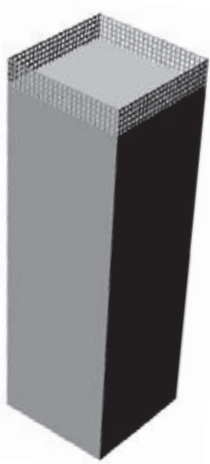

(c) Porosity $50 \%$
Fig. 5 Simulation model

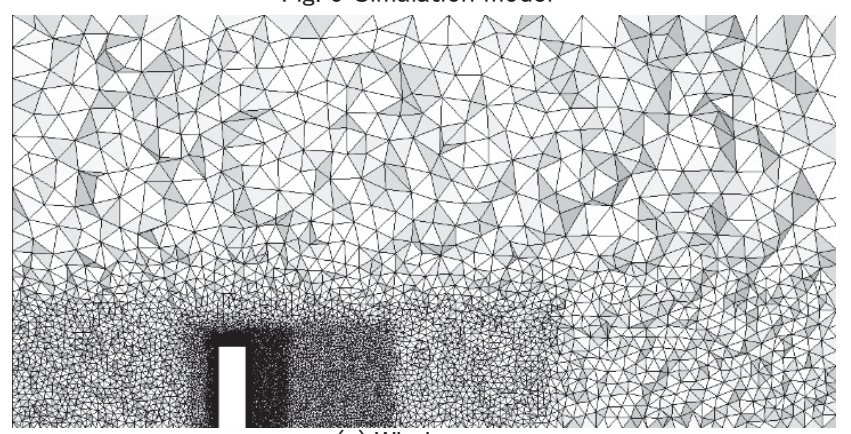

(a) Whole area

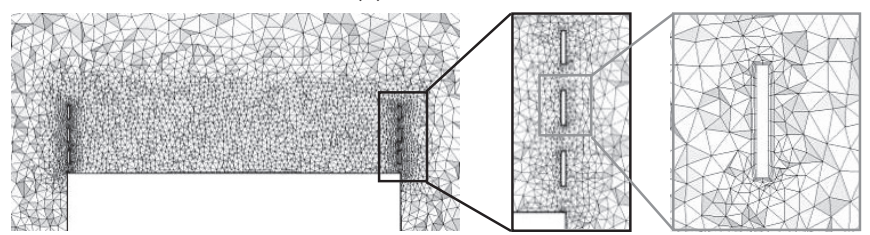

(b) Rooftop

(c) Panel outskirts
線材位置（屋根面から模型寸法で $6.7 \mathrm{~mm}$ と $10.9 \mathrm{~mm}$ の高さ）でサン プリングした結果の平均值から求めることとする。一方， B 面と D 面では開口部の配置が異なるため, 測定孔と同じ位置でサンプリン グしたデータを用いる (Fig.2(b)，(c) 参照)。

さらに，風力係数の鉛直分布を調べるため, Fig.2 に示すように， 風洞実験モデルでの測定点（○印）を通る鉛直線上の数点（○印） でサンプリングする。ただし, 開口率 20\%の場合, 隅角部に最も近 いサンプリング点については, 端から $3 \mathrm{~mm}$ の位置とする。サンプリ ングはパネルの表面と裏面で行っており, サンプリング点の高さは, 開口率 $0 \%$ と $20 \%$ のデルでは，屋根面から $0.1 \mathrm{~mm}, 5 \mathrm{~mm}, 10 \mathrm{~mm}$, $15 \mathrm{~mm}, 19 \mathrm{~mm}$, 開口率 50\%のモデルでは, 屋根面から $2.4 \mathrm{~mm}, 6.7 \mathrm{~mm}$,

10.9mm, 15.1mm, 19.4mm である。

計算領域は, 幅 20B, 奥行 30B, 高さ 15B とし, 建物の中心位置 は，流入境界から8B の距離にある。境界条件は，計算領域の上面お よび側面をフリースリップ, 流出面は表面圧力 $0 \mathrm{~Pa}$ とする。建物壁 面および床面には壁関数 (Werner Wengle 型 3 層モデル) を与え, 境 界層要素としてプリズム要素を 3 層挿入する。乱流境界層について は，別途スパイヤー，ラフネスブロックを再現したモデルを吹走さ せて作成した変動流入風（地表面粗度区分III相当）を与える。

Fig.3 に, 建物中心位置における平均風速比と乱れの強さの鉛直分 布を×印で示す。乱れの強さが実験值に比べて若干小さいが, z/H $<2.0$ の範囲では平均風速比および乱れの強さ共に実験值（○印） と計算值 (X印) が概ね一致している。高さH におけるI は $12.7 \%$, Lxは $36 \mathrm{~cm}$ である。風速のパワースペクトルをFig.4 に示す。

開口率 20\%のモデルにおいて生成された格子の鉛直断面（解析領 域全体, 建物上部と目隠しパネル近傍) をFig.6に示す。格子解像度 は既往の文献 ${ }^{12), 13)}$ を参考に設定している。最も解像度の低い領域は 上空領域であり, 代表寸法はB である。最も解像度の高い領域は目 隠しパネル近傍の領域であり，格子の代表寸法はB/512 である。こ れは, W/15 に相当する (Table 1 中の図参照)。計算格子の総要素数 は開口率 0\%のケースで約 570 万，20\%のケースで約 740 万，50\%の ケースで約 950 万である。

サンプリング間隔は 0.00005 秒（実大約 0.0036 秒相当）とし，実 大約 50 分間相当 (約 850000 ステップ) の計算を行う。外圧係数お よび風力係数を定義するための速度圧は，実験と条件を合わせるた め，建物モデルのない状態で気流を吹走させ，建物モデルの中心位 置における高さH の風速をサンプリングして求めた速度圧 $q_{H}$ であ る。文献 10)では，流入面直後の速度圧を用いて定義しており，若 干值が異なっている。開口部の寸法W（Table1 中の図参照）を代表 長さ, 高さH における風速 $U_{H}$ を代表速度（約 $10 \mathrm{~m} / \mathrm{s}$ ）とし, 空気の 動粘性係数 $v$ を $1.5 \times 10^{-5}\left(\mathrm{~m}^{2} / \mathrm{s}\right)$ とすると, レイノルズ数 $\mathrm{Re}\left(=\mathrm{U}_{\mathrm{H}} \mathrm{W} / v\right)$ は $2.0 \times 10^{3}$ である。また, ピーク值は, 風圧実験と同様に, 平均化 時間を実大相当 0.5 秒とし, 評価時間 10 分間相当の值 5 個のアンサ ンブル平均により評価する。外圧係数および風力係数の符号は風洞 実験結果と同じである。

\section{4. 実験値と計算値の比較}

CFD の精度検証を目的として, Fig.7 と Fig.8 に実験の測定点位置 (Fig.2 参照) であるパネルのほぼ中央高さでのパネル表面 7 点にお ける外圧係数 $\mathrm{C}_{\mathrm{pe}}$, パネル近傍の屋根面 7 点における外圧係数 $\mathrm{C}_{\mathrm{pr}}$, 


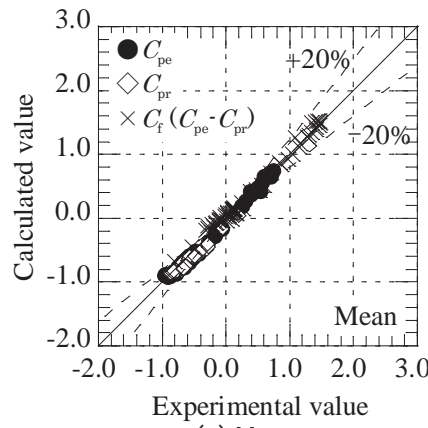

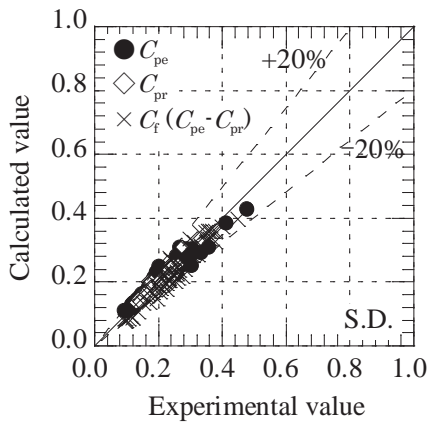

b) Standard deviation

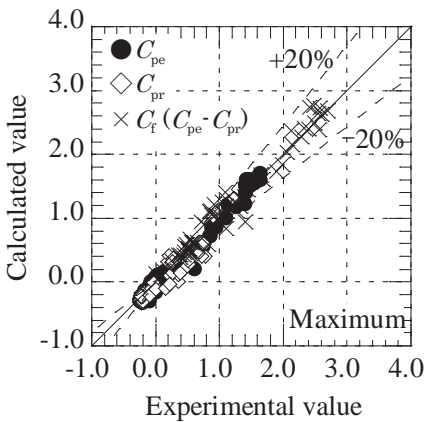

(c) Maximum

Fig. 7 External pressure coefficients and wind force coefficients (Porosity 0 \%)

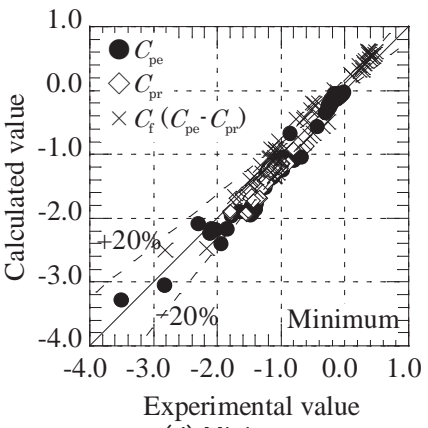

(d) Minimum

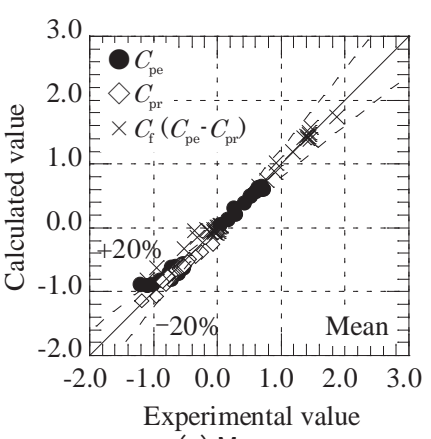

(a) Mean

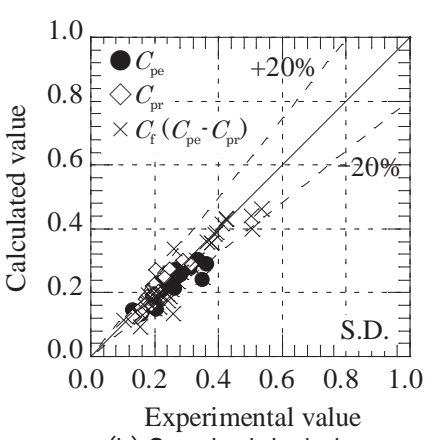

(b) Standard deviation

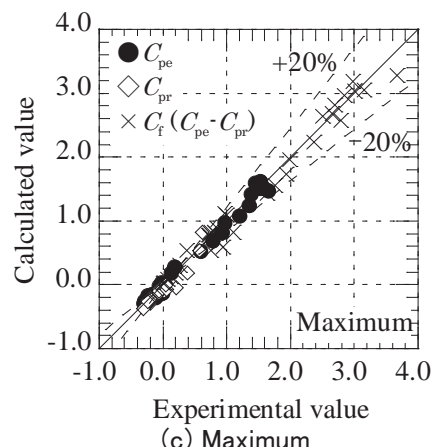

(c) Maximum

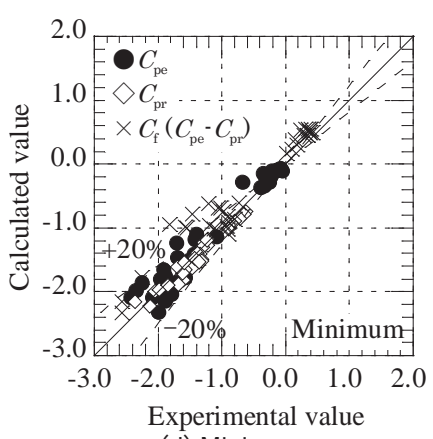

(d) Minimum

Fig. 8 External pressure coefficients and wind force coefficients (Porosity 50 \%)

これらパネル表面圧と屋根面圧の差（時刻歴波形）から求めた 7 点 における風力係数 $\mathrm{C}_{\mathrm{f}}$ について, 風圧実験結果（実験值）とCFD の 結果（計算值）の関係を示す。計算值については建物モデルの対称 性を考慮して風向を読み換えており, 開口率 $0 \%$ の場合は風向 $0^{\circ}$, $20^{\circ}, 45^{\circ}, 70^{\circ}, 90^{\circ}, 110^{\circ}, 135^{\circ}, 160^{\circ}, 180^{\circ}$, 開口率 $50 \%$ の場合は 風向 $0^{\circ}, 45^{\circ}, 90^{\circ}, 135^{\circ}, 180^{\circ}$ の值が示されている。図中の実線は実 験值と計算值が一致するラインであり，破線は実線からの偏差が 土20\%となる範囲を示している。

Fig.7 は，開口率 $0 \%$ の場合における $C_{p e}, C_{p r}, C_{f}$ の結果である。平 均值 (M ean) に関しては実験值と計算值に高い相関がみられ，標準偏 差 (Standard deviation), 最大ピーク值 (M aximum), 最小ピーク值 (M inimum)に関しても，概ね $\pm 20 \%$ の範囲内となっている。開口率 $20 \%$ の場合についても，開口率 $0 \%$ の場合と同様な傾向がみられた。

Fig.8 は, 開口率 50\%の場合における $C_{p e}, C_{p r}, C_{f}$ の結果である。 平均值, 標準偏差, 最大ピーク值については, 開口率 0\%の場合と同 様の傾向を示している。最小ピーク值（Fig.8 (d)) については, $C_{p r}$ $(\diamond)$ はほぼ実線上にあるが， $C_{p e}(\bigcirc)$ と $C_{f}(\times)$ については $20 \%$ 程 度の範囲内に収まっていない（実験值の方が計算值よりも大きい） ケースが見られる。これらは, 風向 $135^{\circ}$ るいは $180^{\circ}$ の結果であり, 実験模型に設置されている導圧管が風上側となる風向であることか ら，パネルの開口率が 50\%のケースでは，風向によって導圧管の影 響が結果に現れている可能性がある。なお, 最大ピーク值 (Fig.8 (c))

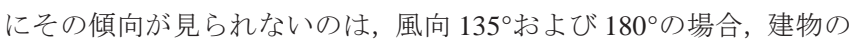
風下側となるパネルの表面に発生する $C_{p e}$ の最大ピーク值が概ね 0 に近いためである。

\section{5.計算結果による屋根面圧とパネル裏面圧の関係}

上述したように, 実験值と計算值が概㸚良い対応を示しているこ
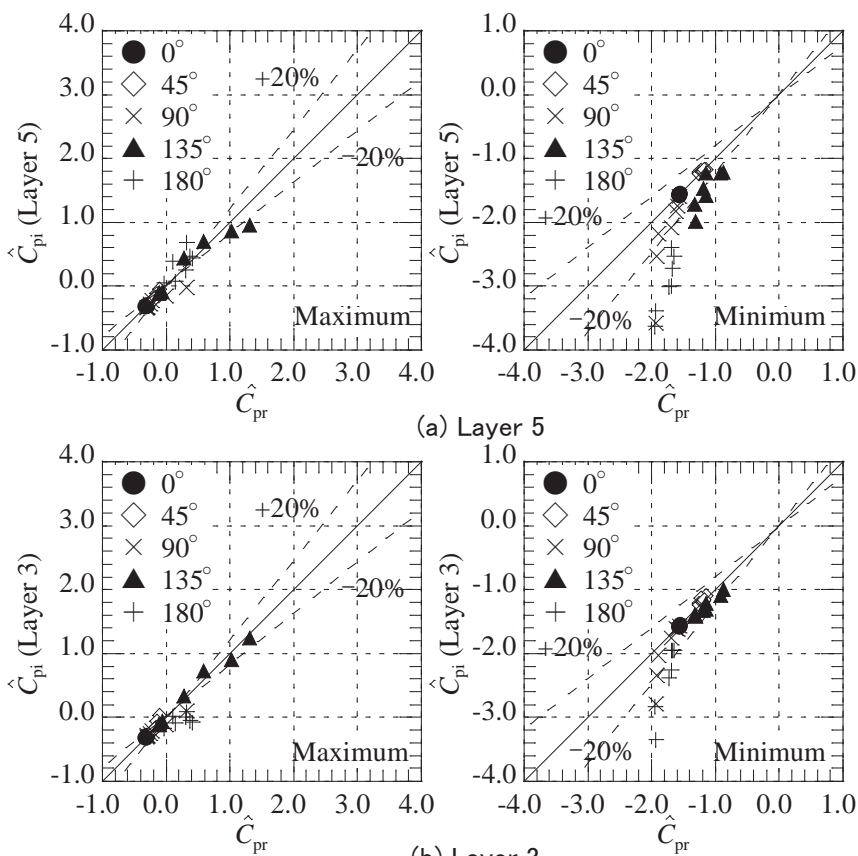

a) Layer 5

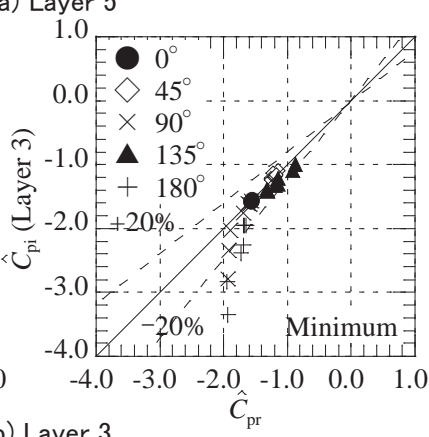

(b) Layer

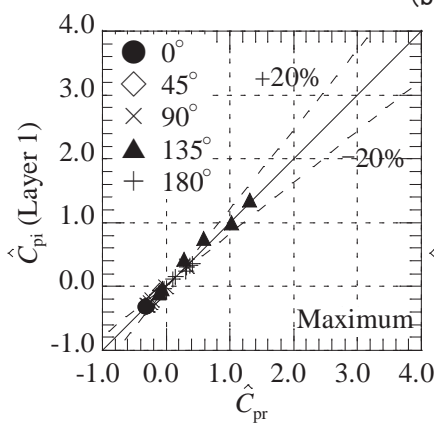

(c) Layer 1

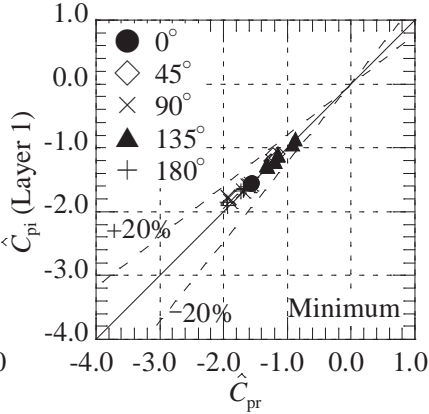

Fig. 9 Relation between $\hat{C}_{\mathrm{pi}}$ and $\hat{C}_{\mathrm{pr}}$ (Porosity $0 \%$ ) 

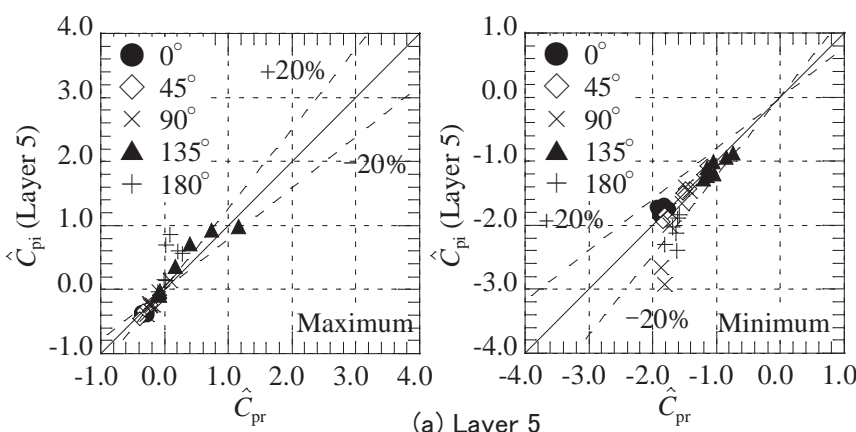

(a) Layer 5
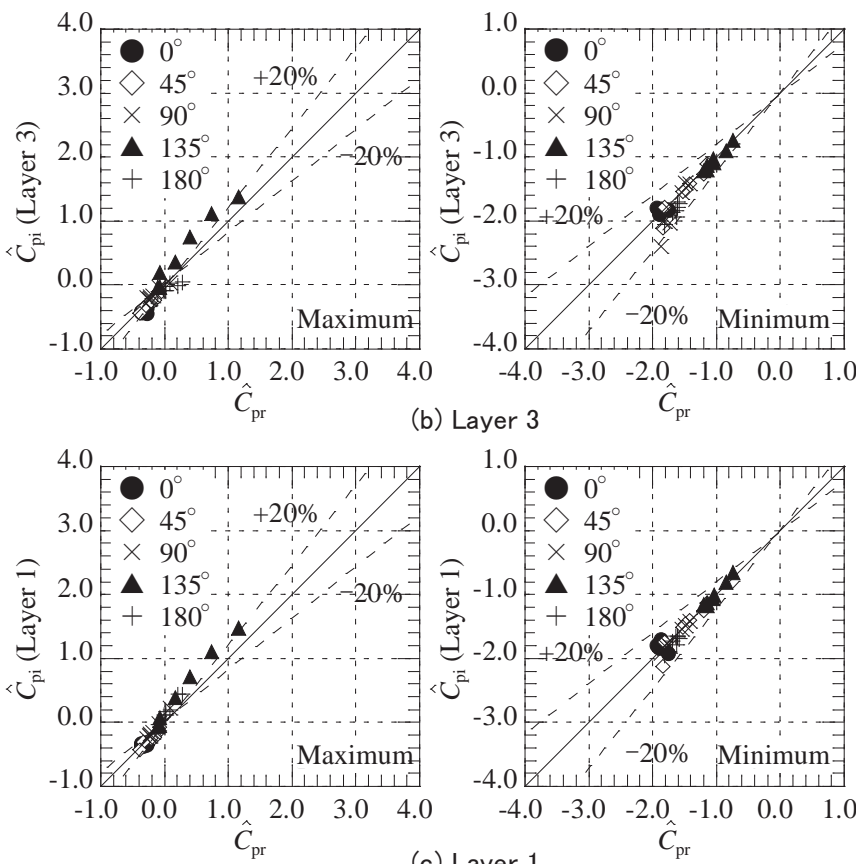

(c) Layer 1

Fig. 10 Relation between $\hat{C}_{\mathrm{pi}}$ and $\hat{C}_{\mathrm{pr}}$ (Porosity $20 \%$ )

とから，本検討で得られた計算值を用いてパネル裏面圧とパネル近 傍の屋根面圧の関係を示し, パネルの風力係数を求める際に, パネ ルの裹面圧としてパネル近傍の屋根面圧を代用する実験手法の妥当 性を検討する。なお, 外圧（風力）係数の最大ピーク值と最小ピー ク值をピーク外圧（風力）係数とする。

Fig.9, Fig.10,Fig.11 は，開口率がそれぞれ 0\%,20\%，50\%の場合 について, パネル近傍の屋根面におけるピーク外圧係数 $\hat{C}_{\mathrm{pr}}$ とパネ ル裏面のピーク外圧係数 $\hat{C}_{\mathrm{pi}}$ の関係である。左の図は各サンプリン グ点におけるピーク外圧係数の最大值 (M aximum), 右の図は最小值 (M inimum) である。Layer 5 は高さ方向に 5 層サンプリングしたう ちの最上層（開口率が $0 \%$ と 20\%ではモデル寸法で屋根面から $19 \mathrm{~mm}$, 開口率 50\% では $19.4 \mathrm{~mm}$ )，Layer 3 は中層（開口率が 0\%と 20\%では $10 \mathrm{~mm}, 50 \%$ では $10.9 \mathrm{~mm}$ ), Layer 1 は最下層（開口率が $0 \%$ と 20\%で は $0.1 \mathrm{~mm}$ ，開口率 $50 \%$ では $2.4 \mathrm{~mm}$ ）を表している。図中の実線は $\hat{C}_{\mathrm{pr}}$ と $\hat{C}_{\mathrm{pi}}$ が一致するラインを示し, 破線は実線からの偏差が $20 \%$ とな る範囲を示している。

開口率が $0 \%$ の場合 (Fig.9), 最下層 (Layer 1)における $\hat{C}_{\mathrm{pr}}$ と $\hat{C}_{\mathrm{pi}}$ の 最小值および最大值，ならびに中層 (Layer 3) および最上層 (Layer 5) における $\hat{C}_{\mathrm{pr}}$ と $\hat{C}_{\mathrm{pi}}$ の最大值には高い相関が見られるが, 中層 (Layer 3)および最上層 (Layer 5) における $\hat{C}_{\mathrm{pr}}$ と $\hat{C}_{\mathrm{pi}}$ の最小值では, 風向 $90^{\circ}(\times)$ と $180^{\circ}(+)$ において, 相関が低くなっている。これは, 風向
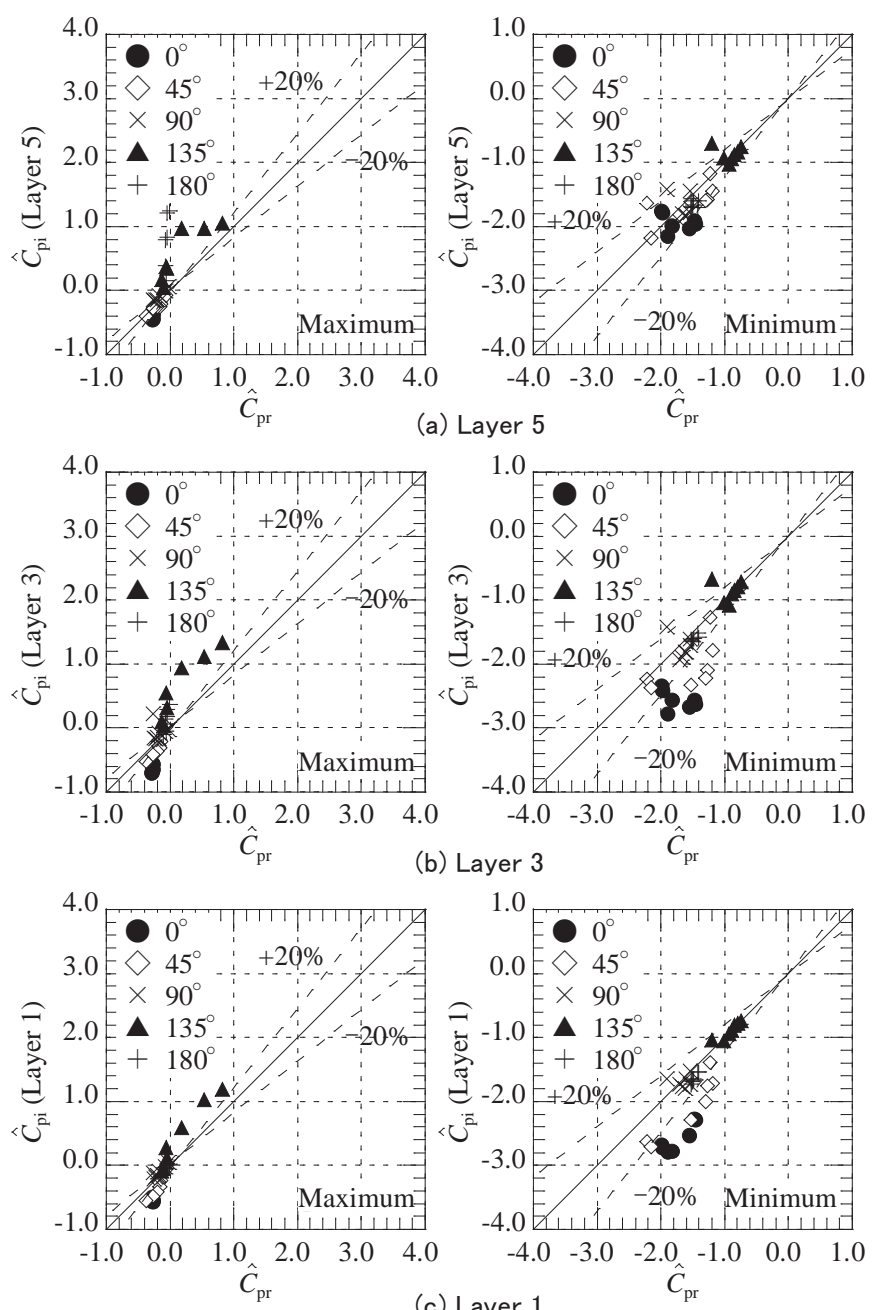

Fig. 11 Relation between $\hat{C}_{\mathrm{pi}}$ and $\hat{C}_{\mathrm{pr}}$ (Porosity $50 \%$ )

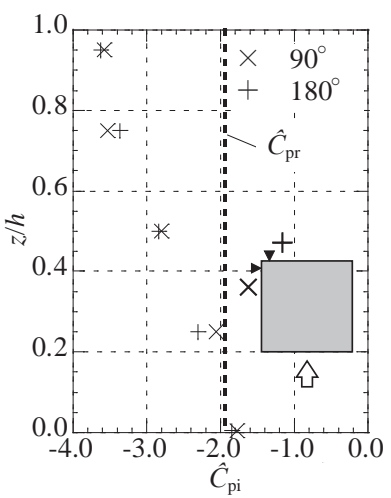

(a) Minimum (Porosity $0 \%$ )

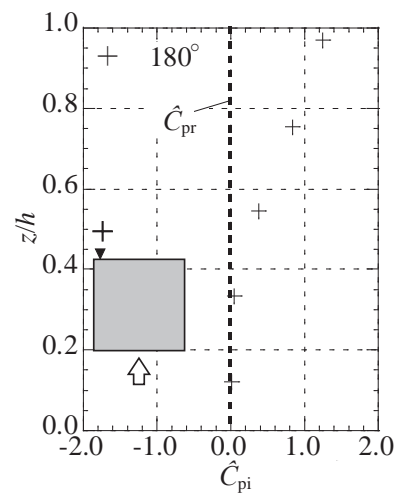

(b) Maximum (Porosity $50 \%$ )

Fig. 12 Distribution of $\hat{C}_{\mathrm{pi}}$ in the vertical direction near the leeward corner

$90^{\circ}(\times)$ と $180^{\circ}(+)$ では, $\hat{C}_{\mathrm{pi}}$ の最小值の絶対值が, サンプリング高 さが高いほど大きくなるような鉛直分布をもつためである。 Fig.12(a)に風下側コーナー部における $\hat{C}_{\mathrm{pi}}$ の最小值の鉛直分布を近 傍における $\hat{C}_{\mathrm{pr}}$ の最小值(図中の破線) と共に示す。これは, Fig.9(a) の右図 (M inimum) において図中の実線から大きく外れた風向 $90^{\circ}$ と $180^{\circ}$ の時の $\hat{C}_{\mathrm{pi}}$ に相当する。z/h（０ が屋根面の高さ， 1 がパネル頂部 高さである）が 0 に近い低層部では $\hat{C}_{\mathrm{pr}}$ と $\hat{C}_{\mathrm{pi}}$ はほぼ同程度の值とな っているが，z/h が 1 に近づくほじ， $\hat{C}_{\mathrm{pi}}$ の絶対值が大きくなってお り，最上層では最下層の 2 倍近い值となっている。 


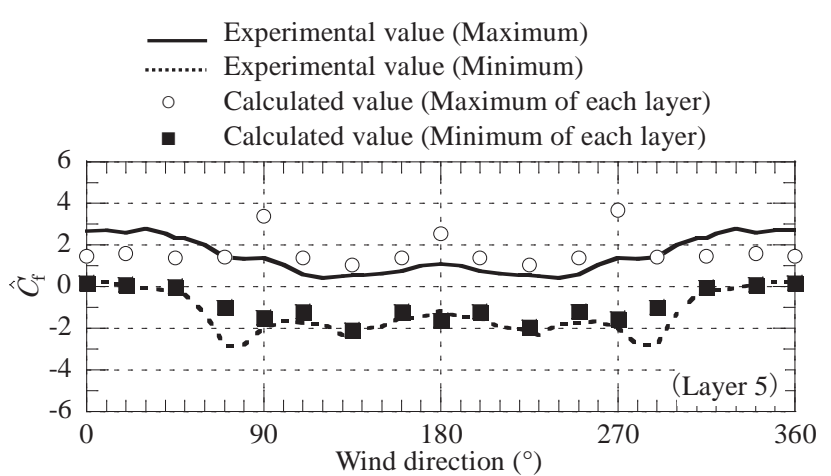

(a) Layer 5

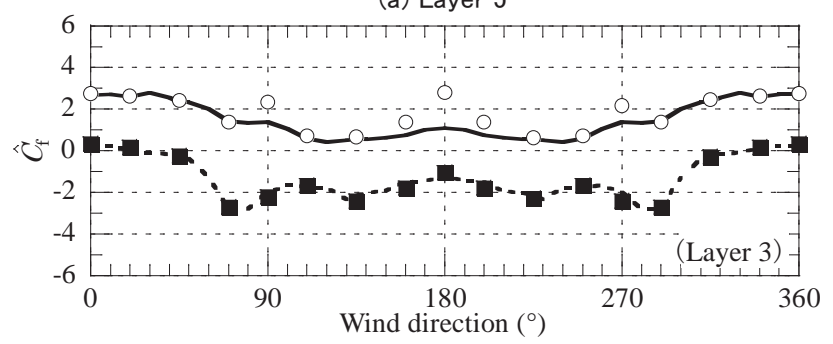

(b) Layer 3

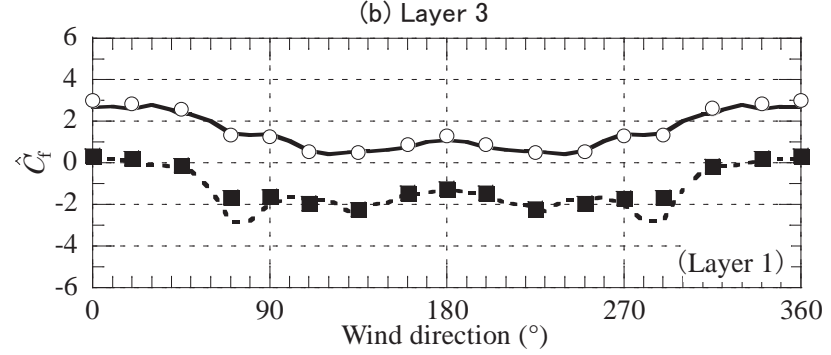

(c) Layer 1

Fig. 13 Variation of $\hat{C}_{f}$ with wind direction (Porosity $0 \%$ )

開口率が 20\%の場合 (Fig.10), 最上層 (Layer 5)において, 開口率 $0 \%$ の場合の中層 (Layer 3) および最上層 (Layer 5) と同じように, 風向 $90^{\circ}(\times)$ と $180^{\circ}(+)$ の時，負の $\hat{C}_{\mathrm{pr}}$ と $\hat{C}_{\mathrm{pi}}$ の相関が若干低くなる傾向 が見られるが，中層(Layer 3) ではそのような傾向はほとんど見られ ない。これは，開口率が $20 \%$ 程度の場合，屋根面圧とパネル裏面圧 （下層）の相関は，開口率 $0 \%$ の場合と同様に高く，なおかつ，パネ ルの表面と裏面の圧力が等圧化することで，風圧の鉛直分布が一様 に近づくためと考えられる。なお，開口率が $0 \%$ おび 20\%の場合 において， $\hat{C}_{\mathrm{pr}}$ と $\hat{C}_{\mathrm{pi}}$ の最小值の相関が低くなるのは，屋根面の風下 側となるコーナー部（風向 $90^{\circ}$ では端部 $E$, 風向 $180^{\circ}$ では端部 $E$ と F）であった。

開口率が 50\%の場合 (Fig.11), 開口率 0\%や 20\%の場合と比較し て，全体的に $\hat{C}_{\mathrm{pr}}$ と $\hat{C}_{\mathrm{pi}}$ の相関が低い傾向が見られるが，開口率 $20 \%$ の場合と同様に，最上層(Layer 5) を除いて中層 (Layer 3)および最下 層 (Layer 1) に大きな違いは見られない。これは，開口率が大きくな ったことで，屋根面圧とパネルの裏面圧の相関はいくらか低くなる が，パネルに通気性があることにより $\hat{C}_{\mathrm{pi}}$ の鉛直分布が一様に近づ くためと考えられる。Fig.12(b) に風下側コーナー部における $\hat{C}_{\mathrm{pi}}$ の 最大值の鉛直分布を近傍における $\hat{C}_{\mathrm{pr}}$ の最大值(図中の破線) と共に 示す。これは, Fig.11(a)の左図 (M aximum)において図中の実線から 大きく外れた風向 $180^{\circ}$ の時の $\hat{C}_{\mathrm{pi}}$ に相当する。 $\mathrm{z} / \mathrm{h}$ が 0.5 を超えたあ たりから 1 に近づくにつれ， $\hat{C}_{\mathrm{pi}}$ が大きくなっており，最下層で 0 程 度であった值が最上層では 1 程度の值となっている。なお，屋根面

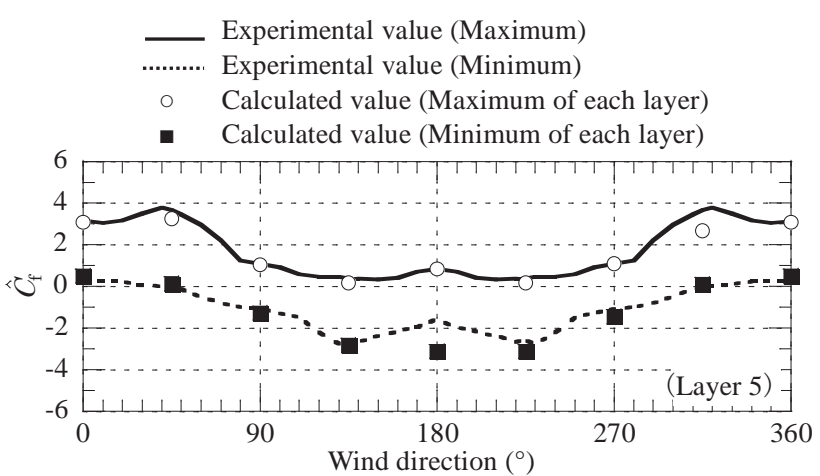

(a) Layer 5

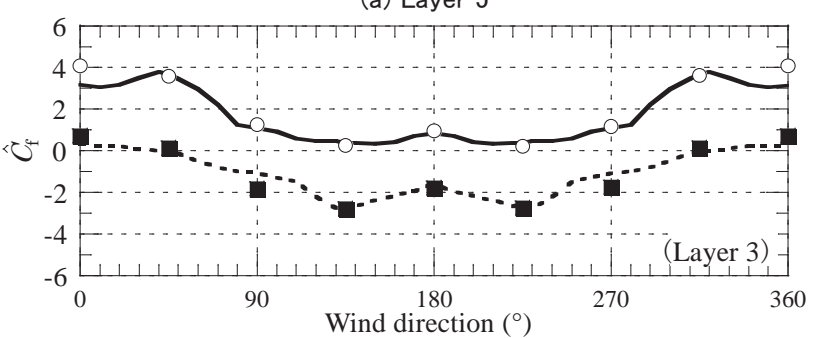

(b) Layer 3

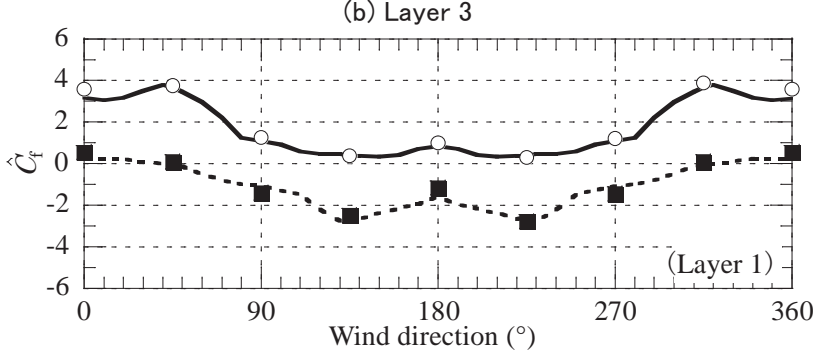

(c) Layer 1

Fig. 14 Variation of $\hat{\mathcal{C}_{\mathrm{f}}}$ with wind direction (Porosity $50 \%$ )

に最も近い最下層 (Layer 1)においても $\hat{C}_{\mathrm{pr}}$ と $\hat{C}_{\mathrm{pi}}$ の相関が低いのは, 開口率 50\%の場合, サンプリング高さがモデル寸法で屋根面から $2.4 \mathrm{~mm}$ であり, 開口率が $0 \%$ や $20 \%$ の場合 $(0.1 \mathrm{~mm})$ よりも屋根面か ら離れていることも原因のひとつと考えられる。

\section{6. 屋上目隠しパネルの風力係数}

6. 1 パネル面の各層における最大 - 最小ピーク風力係数

Fig.13 およびFig.14に, 開口率が 0\%および 50\%の場合について, 各層で得られたパネルの表面圧と裏面圧の差（時刻歴波形）から求 めた 7 点中最大および最小のピーク風力係数 $\hat{C}_{f}$ (計算值) の風向に よる変化を実験值（パネルのほぼ中央高さにおける表面圧とパネル 近傍の屋根面圧の差から算出した值）と共に示す。実験結果におけ る風向 $180^{\circ} \sim 360^{\circ}$ の值は $0^{\circ} \sim 180^{\circ}$ の值を風向を読み換えて用いてい る。これらの結果は, Fig.9およびFig.11に示したパネル近傍の屋根 面のピーク外圧係数 $\hat{C}_{\mathrm{pr}}$ とパネル裏面のピーク外圧係数 $\hat{C}_{\mathrm{pi}}$ の関係と 似た傾向を示している。なお，Fig.7 とFig.8 において計算值として 示した $C_{f}$ のピーク值は, 実験值と同様にパネルのほぼ中央高さにお けるパネル表面圧とパネル近傍の屋根面圧の差（時刻歷波形）から 求めた值であり, Fig.13 と Fig.14 に示す $\hat{C}_{f}$ （計算値）とは異なる。

開口率が $0 \%$ の場合 (Fig.13), $\hat{C}_{f}$ の最小値については計算値と実 験值に大きな違いは見られず, 全風向中の最小值は-3 程度である。 $\hat{C}_{f}$ の最大值については, 中層 (Layer 3) と最上層 (Layer 5) の風向 $90^{\circ}$, $180^{\circ}, 270^{\circ}$ 付近において計算值が実験值を上回っており，全風向中 
の最大値は 4 程度である。これは, Fig.12(a)に示したように $\hat{C}_{\mathrm{pi}}$ の 最小值の絶対值が上層ほど大きくなるためである。なお，開口率が $20 \%$ の場合は，最上層(Layer 5) において若干の違いが見られるが， 最下層 (Layer 1) と中層 (Layer 3) においては, $\hat{C}_{f}$ の最大值, 最小值共 に実験值と計算值の違いはほとんどなく, 全風向中の最大值は 3.5 程度，全風向中の最小值は-2.5 程度であった。

開口率が $50 \%$ の場合 (Fig.14)， $\hat{C}_{\mathrm{pr}}$ と $\hat{C}_{\mathrm{pi}}$ の相関は全体的にやや低 いが (Fig.11), 各層共に $\hat{C}_{f}$ の最大值，最小值を見ると実験值と計算 值の違いはほとんど見られず, 全風向中の最大值は 4 程度, 最小值 は-3.5 程度である。これは, 風向 $0^{\circ}$ の中層 (Layer 3) を除いて $\hat{C}_{f}$ の 最大值および最小值の発生部位が概ねコーナー部付近であったこと から，コーナー部付近では $\hat{C}_{\mathrm{pr}}$ と $\hat{C}_{\mathrm{pi}}$ の相関が比較的高いためと考え

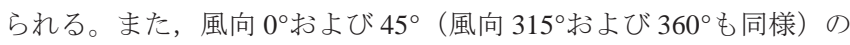
時の $\hat{C}_{\mathrm{f}}$ の最大值は，サンプリング高さによらず，開口率 $0 \%$ の場合 よりも大きな值となっている。これは, Fig.9(c)と Fig.11(c)の右図 (Layer 1 の Minimum) を見ると， $\hat{C}_{\mathrm{pr}} ， \hat{C}_{\mathrm{pi}}$ 共に開口率 $50 \%$ の方が開 口率 $0 \%$ の場合よりも絶対值で大きな值となっていることによるも のと考えられる。なお, Fig.12(b)に示したように $\hat{C}_{\mathrm{pi}}$ の最大值が中 層 (Layer 3) から最上層 (Layer 5) にかけて大きくなることから，風向 $180^{\circ}$ の時の最上層 (Layer 5) における $\hat{C}_{f}$ の最小值の絶対值が他の層 (Layer 1 と Layer 3) よりも大きいが，風向 $135^{\circ}\left(225^{\circ}\right)$ の值と同程 度であるため全風向中の最小值に影響を与えるほどではない。

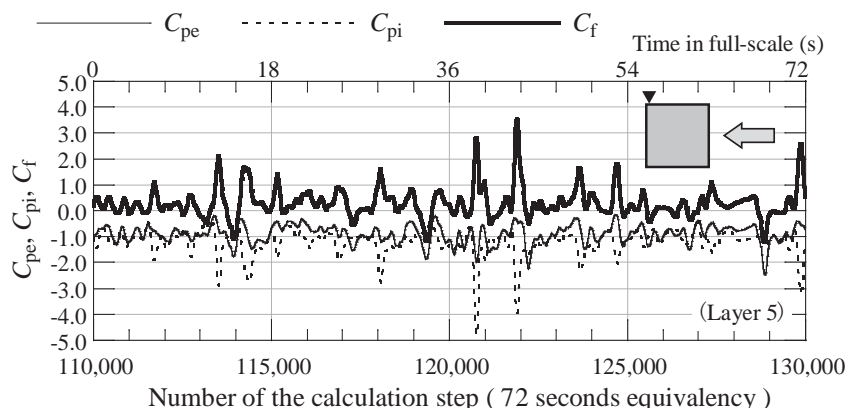

(a) Layer 5

Time in full-scale (s)

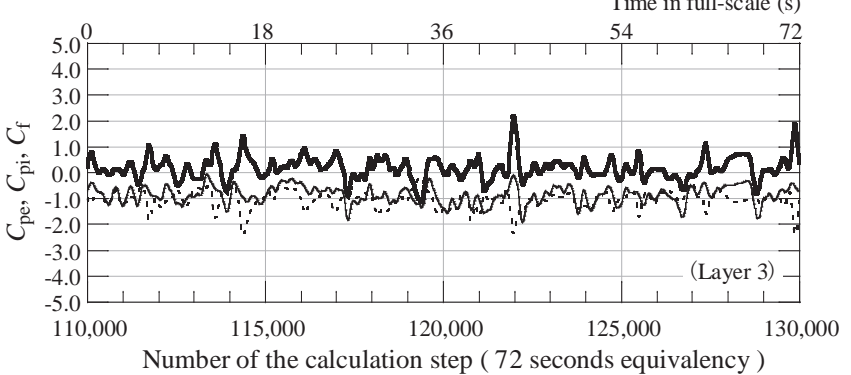

(b) Layer 3

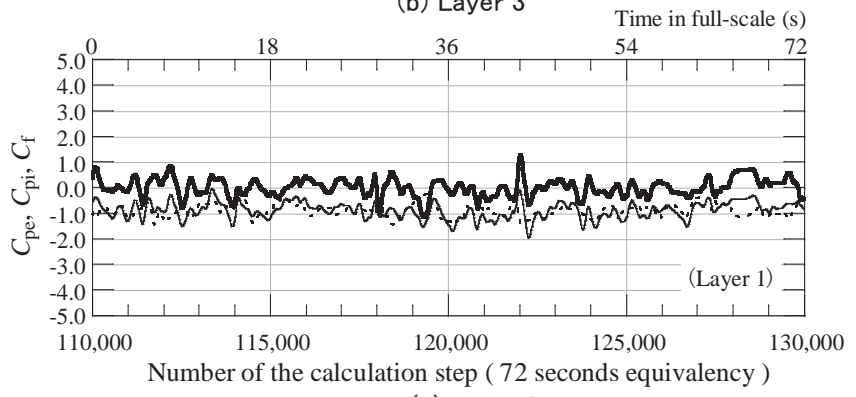

(c) Layer 1

Fig. 15 Time series (Porosity $0 \%$, Maximum value of $C_{\mathrm{f}}$ )

\section{2 ピーク風力係数発生時前後の $C_{p e}, C_{p i}, C_{f}$ の時刻歴波形}

Fig.15 に開口率 $0 \%$ の場合について, パネル最上層 (Layer 5)にお いて $\hat{C}_{\mathrm{f}}$ の最大值が発生した平面位置（実験条件としてはFig.1 (b)に 示す風向 $90^{\circ}$ の時の端部 $E$ に相当する) における実時間で 72 秒間相 当の $C_{p e}, C_{p i}, C_{f}$ の時刻歴波形を示す。横軸上部は実時間, 下部は計 算ステップを示す。なお, この波形は実時間 0.5 秒相当の平均化処 理（移動平均個数 140 個）を行った後の波形である。最下層 (Layer 1), 中層 (Layer 3), 最上層(Layer 5) と高さが高くなるにつれ, $C_{p e r}$ $\mathrm{C}_{\mathrm{pi}}, \mathrm{C}_{\mathrm{f}}$, いずれにおいても, 振幅が大きくなる傾向が見られる。この 平面位置は建物の風下側となることから, 各層において, $C_{p e}$ と $C_{p i}$ は概ね同じような変化をしている。ただし, 最上層 (Layer 5) の計算 ステップ 122,000 付近では, $C_{\mathrm{f}}$ が 4 程度の值となっている時, $\mathrm{C}_{\mathrm{pi}}$ が 強く負側に振れているのに対し， $C_{p e}$ は正側に振れているのがわかる。

Fig. 16 に, 開口率 50\%の場合について, パネル最上層 (Layer 5)に おいて $\hat{C}_{\mathrm{f}}$ の最小值が発生した平面位置（実験条件としてはFig.1 (b) に示す風向 $180^{\circ}$ の時の端部 $F$ に相当する）における実時間で 72 秒 間相当の $C_{p e}, C_{p i}, C_{f}$ の時刻歴波形を示す。横軸上部は実時間, 下部 は計算ステップを示す。この平面位置についても, Fig.15 の場合と 面は異なるものの, 風下側コーナー部という点で一致している。し かし,Fig.15 とは異なり $\hat{C}_{\mathrm{f}}$ が負側に大きく振れている。最上層 (Layer 5)の計算ステップ 125,000 付近を過ぎたあたりで, C $\mathrm{f}$ が-3.5 程度の 值となっている時 $C_{\mathrm{pi}}$ が正側に振れているのに対し， $C_{p e}$ は負側に振

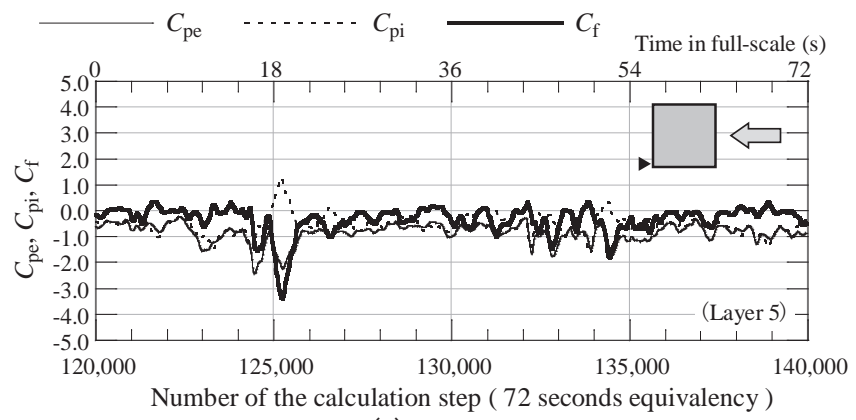

(a) Layer 5

Time in full-scale (s)

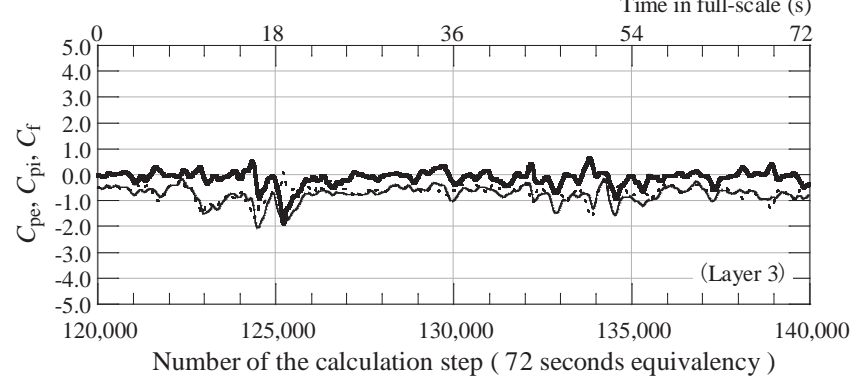

(b) Layer 3

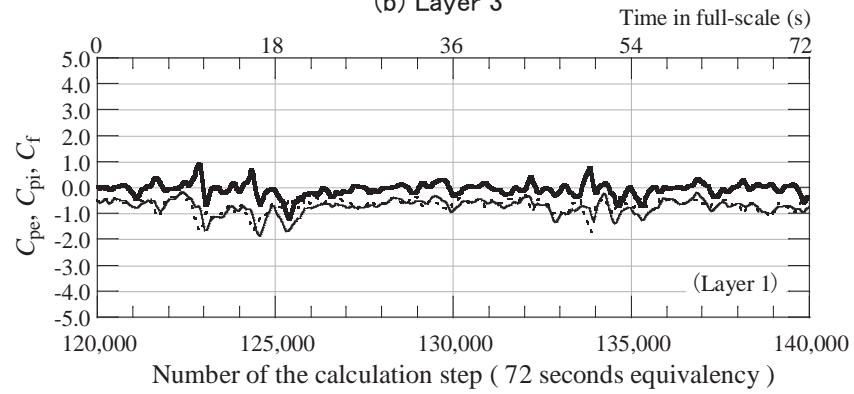

(c) Layer 1

Fig. 16 Time series (Porosity $50 \%$, Minimum value of $C_{\mathrm{f}}$ ) 


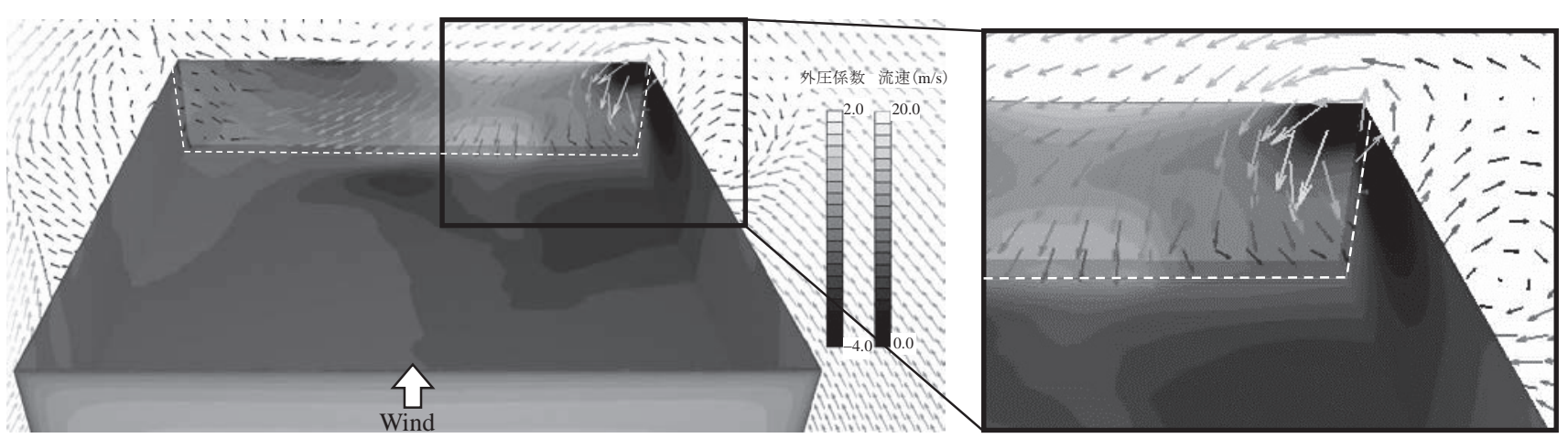

Fig. 17 External pressure coefficient distribution and wind speed vector of the plumb cut surface (Porosity $0 \%$ )

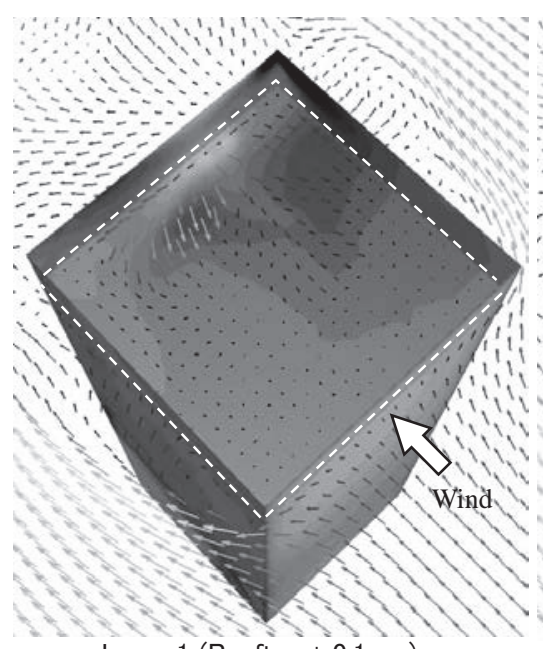

Layer 1 (Rooftop $+0.1 \mathrm{~mm}$ )

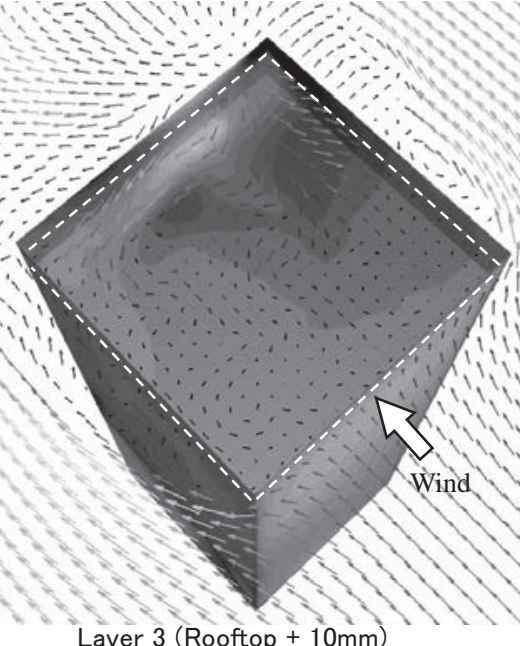

Layer 3 (Rooftop $+10 \mathrm{~mm}$ )

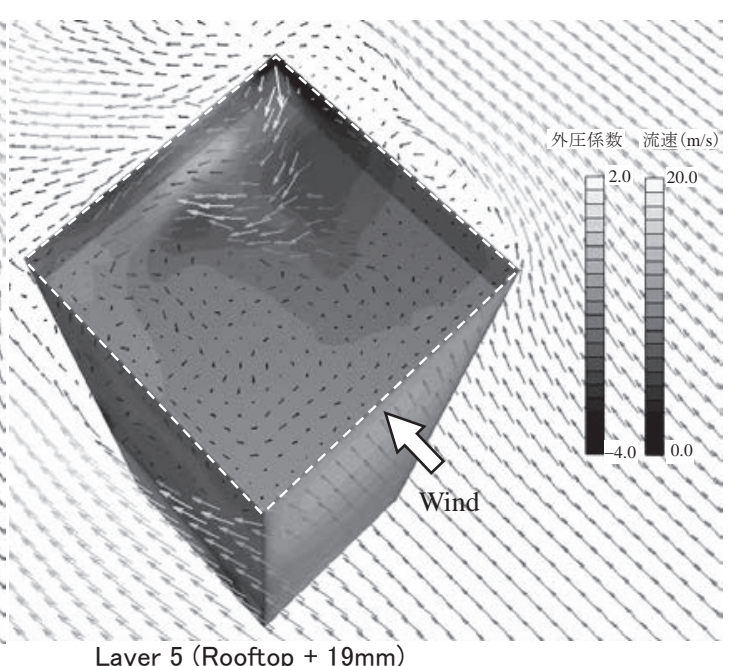

Layer 5 (Rooftop $+19 \mathrm{~mm}$ )

Fig. 18 External pressure coefficient distribution and wind speed vector in the horizontal cut surface (Porosity $0 \%$ )

れているのがわかる。また, 開口率 $0 \%$ のパネルで見られたサンプリ ング高さによる違いは明瞭ではなく, 最下層 (Layer 1) と中層 (Layer 3)ではほとんど違いが見られない。なお，開口率 20\%のパネルにつ いては, 開口率 50\%のパネルと同様の傾向が見られたが, 開口率 50\% の場合ほど明瞭な $\mathrm{C}_{\mathrm{pi}}$ および $\mathrm{C}_{\mathrm{f}}$ のピークは見られなかった。

\section{3 ピーク風力係数発生時の流れ場}

CFD の結果を用いて, 最大・最小ピーク風力係数の発生メカニズ ムについて検討する。田村らは，文献 7)の実建物を対象とした風洞 実験と同じモデルを用いた, 大容量・高速度計算システムによる精 緻な数值流体解析を実施しており, 流れの可視化により, 風向角 $65^{\circ}$ （面に正対する風向が $0^{\circ}$ ）の時, 風上側の屋上目隠しパネルを越え た流れが剥離して風下側の屋根面に再付着寸ることで，パネルの風 下側端部において最小ピーク風力係数が絶対值で大きくなることを 示している ${ }^{14)}$ 。これは, 本論文の実験条件における, 風向 $115^{\circ}$ の端 部 E に相当する。一方, Fig.13 に示した風向 70で発生している最 小ピーク風力係数の発生位置は端部 Fであり, 発生位置が異なって いる。これは，建物形状や周辺建物の有無などが本モデルとは異な るため，流れ場の状況も異なっているものと考えられる。

本検討では，6.2 節で示した開口率 0\%の場合について，Cf の最大 ピーク值発生時, 並びに, 開口率 $50 \%$ の場合について, Cf の最小ピ 一ク值発生時における気流の流れ場について述心゙る。

Fig.17 に, 開口率 0\%の屋上目隠しパネルを有する建物の屋上付近 における外厓係数分布と，風上側の壁面から模型寸法で $95 \mathrm{~mm}$ 風下 側となるカット面(風向と直角な面)における流速ベクトルを示す。

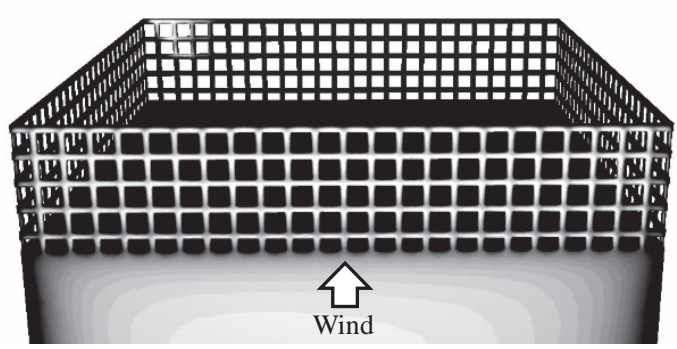

外圧倸数

Fig. 19 Distribution of external pressure coefficient (Porosity $50 \%$ )

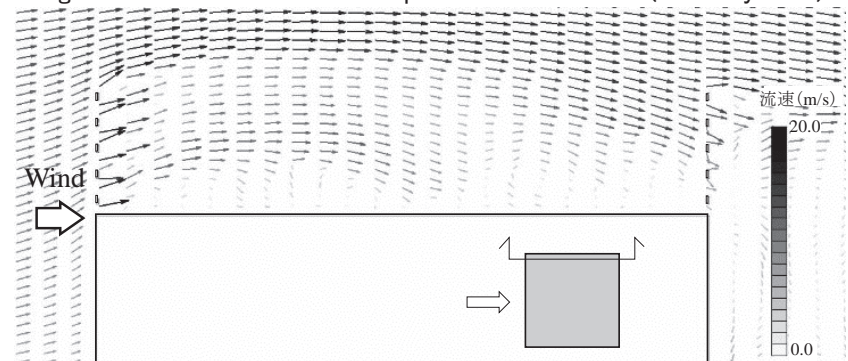

Fig. 20 Wind speed vectors in the vertical plane near the side wall

(Porosity $50 \%$ )

この図は, 風下側コーナー部においてパネルの裏面に大きな負圧が 発生した瞬間（Fig.15 の計算ステップ 120,800 付近）の外圧係数分 布および流速ベクトルである。風下側のコーナー部（Fig.17 の右奥 コーナー部）において, 目隠しパネルの外側から内側に風が巻き込 んでいるような流れが示されており，パネルの中央高さより高い位 置で流速が大きく（色は白く, ベクトルは長く）なっている。この ような現象は，左奥のコーナー部にも発生する。 
Fig.18には, Fig.17 と同時刻における開口率 0\%の屋上目隠しパネ ルの最下層 (Layer 1), 中層 (Layer 3), 最上層(Layer 5)の位置でカッ トした面における流速ベクトルを示す。最上層（Layer 5) では，風下 側コーナー部において流速が大きく, 流速ベクトルは下向き（対角 のコーナ部方向) となっているが, 中層 (Layer 3), 最下層 (Layer 1) ではそのような流れは見られない。このようなパネルの上層部に発 生する渦の影響により, 風下側コーナー部の風力係数が鉛直分布を もつと考えられる。

Fig.19 と Fig.20には, 開口率 50\%の屋上目隠しパネルを有する建 物の屋上付近の外圧係数分布と, 風上側から見て左側面から模型寸 法で $5.5 \mathrm{~mm}$ 右のラインでカットした面（風向に平行な面）における 流速ベクトルを示す。これらの図は，風下側コーナー部（風上側か ら見て左奥) においてパネルの風力係数が最小值となる瞬間 (Fig.16 の計算ステップ 125,200 付近）の外圧係数分布と流速ベクトルであ り, Fig.14(a)において風向 $180^{\circ}$ の時にパネル最上層(Layer 5)の $\hat{C}_{\mathrm{f}}$ の最小值が他の層よりも絶対值で大きい值を示した瞬間の外圧係数 分布と流速ベクトルに相当する。

Fig.19 では, 風下側コーナー部（左側）に発生する $C_{p i}$ の最大ピー ク值を見やすく表示するため, 外圧係数が 0 以下の面は黒, 1.4 以上 の面は白で表示されている。Fig.19 を見ると, 風下側コーナー部 (左 側）のパネル上層部において $\mathrm{C}_{\mathrm{pi}}$ が局所的に大きく（色が白く）なっ ている(外圧係数 1 程度)。この時風下側コーナー部では, 風上側の パネル開口部を通過した風やパネルの上端部を超えた風が風下側の パネル裏面上層部に再付着していることが Fig.20 から見てとれる。 このため, Fig.14 で示したように風向 $180^{\circ}$ における $\hat{C}_{\mathrm{f}}$ の最小值が 最上層のみ絶対值で大きな值となったと考えられる。

また，Fig.20を見ると風上側（左側）のパネル付近において，パ ネルの開口部を通過する流速が大きくなっている（見やすいように Fig.17, Fig.18 とは流速の色を逆にし, 色は黒く, ベクトルは長い)。 このことから， 6.1 節にて述べた風上側における $\hat{C}_{\mathrm{pr}}$ および $\hat{C}_{\mathrm{pi}}$ が開 口率 $0 \%$ の場合よりも開口率 $50 \%$ の方が絶対值で大きな值となって いる原因は, 開口率 50\%のパネルの場合, 風上側屋根面端部で剥離 した強い風が開口部を通過するためであると考えられる。

\section{7. まとめ}

筆者らによる既往の風圧実験と同じモデルを対象とし，LES を用 いたCFD を実施した結果，以下のことが明らかとなった。

(1)屋上目隠しパネルの開口率が $0 \%$ の場合, 風下側コーナー部に おいて, パネルの高さ位置が高くなるほどピーク風力係数の絶 対值が大きくなる要因と考えられる流れ場を確認した。

(2)屋上目隠しパネルの開口率が 20\%の場合, 多少の通気性をもつ ことにより, パネルの裏面圧とパネル近傍の屋根面圧の相関が 高い状態を保ったまま，パネルの風力係数の鉛直分布が一様に 近づくため, パネルの裏面圧として屋根面圧を用いて風力係数 を評価することの妥当性が示された。

(3)屋上目隠しパネルの開口率が $50 \%$ の場合, 開口率 20\%のパネル よりも風を通しやすくなるため, パネルのピーク風力係数の鉛 直分布は, 風向が建築物の壁面に正対する場合における風下側 コーナー部を除いて開口率 20\%のパネルよりも一様に近づくが, パネルの裏面圧とパネル近傍の屋根面圧の相関が低くなる。た
だし, パネルの最大・最小ピーク風力係数に関しては, 発生す る風向（建築物の壁面に対して $45^{\circ}$ の斜め方向）および部位（コ 一ナー部）におけるパネルの裏面圧と屋根面圧の相関が高く, 上述した風下側コーナー部における風力係数の鉛直方向の変化 もさほど大きくないため, パネルの裏面圧として屋根面圧を代 用して求めたピーク風力係数を用いることが可能である。

(4)開口率 $50 \%$ の屋上目隠しパネルの風下側コーナー上層部におい て, 最小ピーク風力係数が発生する瞬間の流れ場を明確にした。 (5)屋上目隠しパネルのピーク風力係数は, 開口率によらず概ね \pm 4 となった。

\section{参考文献}

1) Architectural Institute of Japan: Recommendations for Loads on Buildings, M aruzen, 2015.2 (in Japanese)

2) A rchitectural Institute of Japan: $M$ anual of Cladding W ind Resistance Evaluation for Designers and Engineers, M aruzen, pp.105-106, 2013.2 (in J apanese)

3) Stathopoulos, T., Saathoff, P. and Du, X.: Wind loads on parapets, J ournal of W ind Engineering and Industrial A erodynamics, Vol.90, pp.503-514, 2002.5

4) Ohtake, K.: Peak wind pressure coefficients for cladding of a large roof, Summaries of Technical Papers of A nnual M eeting A rchitectural Institute of J apan, Structures I, pp.217-218, 2008.9 (in J apanese)

5) Honda, H., Kurita, T., Katou, N. and Komi, T.: A study of peak wind force coefficients for screen standing on rooftop, Summaries of Technical Papers of A nnual M eeting A rchitectural Institute of J apan, Structures I, pp.185-186, 2015.9 (in J apanese)

6) Tagawa, Y., Kikuchi, H. and Tamura Y.: Characteristics of peak wind force coefficients acting on rooftop, Summaries of Technical Papers of A nnual $M$ eeting A rchitectural Institute of J apan, Structures I, pp.215-216, 2016.8 (in J apanese)

7) Itoh, Y., Kondo, K., Kikuchi, H., N ozu, T., Ohtake, K., Tanaka, H., Kawai, H. and Tamura, T.: Application of CFD technique to wind-resistant design of buildings Part 2 Wind tunnel experiment for office and residential type tall buildings, Summaries of Technical Papers of A nnual M eeting A rchitectural Institute of J apan, Structures I, pp.235-236, 2016.8 (in J apanese)

8) Hattori, A., Tokui, M., M inowa, K., Ogawa, T., M asuda, K. and Sasaki, Y.,: CHARACTERISTICS OF WIND PRESSURE ON ROOFS OF LARGE-SCALE BUILDINGS WITH WALLS ON THE ROOFTOP, Journal of Structural and Construction Engineering (Transactions of AJ), Vol.81, No.728, pp.1627-1634, 2016.10 (in J apanese)

9) Aihara, T. and Uematsu, Y.: A STUDY OF WIND LOADS ON PERMEABLE PANELS PLACED ALONG THE PERIMETER OF THE ROOFTOP OF A HIGHRISE BUILDING, Proceedings of the 23rd National Symposium on Wind Engineering, pp.391-396, 2014.12 (in Japanese)

10) Aihara, T. and Uematsu, Y.: WIND FORCES ON PERMEABLE PANELS PLACEd ALONG THE PERIMETER OF THE ROOFTOP OF A HIGH-RISE BUILDING -Discussion of Wind Tunnel Technique Based on a Comparison with Large Eddy Simulation-, Proceedings of the 24th National Symposium on Wind Engineering, pp.229-234, 2016.12 (in J apanese)

11) Aihara, T. and A sami, $Y$.: D rag coefficient of permeable cladding for wind tunnel test, Summaries of Technical Papers of A nnual M eeting A rchitectural Institute of Japan, Structures I, pp.119-120 2009.8 (in Japanese)

12) Yoshikawa, M. and Tamura, T.: EVALUATION OF FLUCTUATING WIND PRESSURES ON 3D SQUARE CYLINDER BY UNSTRUCTURED-GRID LES Formulation of LES using unstructured grid system for wind-resistant design of buildings (Part 1) -, Journal of Structural and Construction Engineering (Transactions of AlJ), V ol.78, No.687, pp.913-921, 2013.5 (in Japanese)

13) Yoshikawa, M. and Tamura, T.: WIND LOAD ESTIMATION OF VERTICAL FINS ON WALLS OF HIGH-RISE BUILDING - Formulation of LES using unstructured grid system for wind-resistant design of buildings (Part 3) -, J J ournal of Structural and Construction Engineering (Transactions of AlJ), Vol.81, N 0.722 , pp.665-674, 2016.4 (in J apanese)

14) Tamura, T., Kondo, K., Kataoka, H. and Kawai, H.: ESTIMATION OF WIND LOADS ON ACTUAL BUILDING BY COMPUTATIONAL FLUID DYNAMICS, Proceedings of the 24th National Symposium on Wind Engineering, pp.253-258, 2016.12 (in J apanese) 


\title{
WIND FORCES ON POROUS PANELS PLACED ALONG THE PERIMETER OF THE ROOFTOP OF HIGH-RISE BUILDING
}

\author{
Tomoko AIHARA* and Yasushi UEMATSU** \\ * Research Engineer, Technology Center, TAISEI CORPORATION \\ ** Prof., Dept. Architecture and Building Science, Graduate School of Engineering, Tohoku University, Dr.Eng.
}

Blind panels are often attached to the rooftop of a building along its perimeter to keep outdoor equipment from sight. Permeable materials are generally used in order to cool the equipment by winds. Furthermore, it is expected that the wind loads on such panels are smaller than those on solid panels. Previous studies of wind loads on blind panels mainly focused on solid panels. Few studies have been made of permeable panels.

The present paper investigates the wind force coefficients on solid and permeable blind panels installed on the rooftop of a high-rise building based on a wind tunnel experiment and a CFD simulation with LES, in which the porosity is changed from 0 to $80 \%$.

In Chapter 1, the background and objective of the present study are first described. Then, the previous studies of wind loads on blind panels are reviewed.

Chapter 2 briefly explains the wind tunnel experiment on the wind loads on blind panels attached to the rooftop of a high-rise building. In the experiment, perforated thin panels with porosity of $0,20,50$ and $80 \%$ are used for the blind panels. Considering the difficulties in model making and pressure measurements on permeable panels, the wind pressure coefficients on the rooftop near the panel are used for those on the panel's interior surface for evaluating the net wind force coefficients on the blind panel.

Chapter 3 describes the CFD simulation technique with LES applied to the wind tunnel experiments, in which the wind loads on and the flow field around the blind panels with porosity of 0,20 and $50 \%$ are investigated.

In Chapter 4, the CFD simulation technique is first verified by comparing the results with those of the wind tunnel experiment. A relatively good agreement between CFD and wind tunnel experiment is obtained.

In Chapter 5, the relation between the wind pressure coefficient on the rooftop near the blind panel and the panel's interior surface is investigated based on the CFD. Regarding the solid panels, large negative pressure coefficients are induced on the upper part of the corner. In such a case, the above-mentioned wind tunnel experiment may underestimate the design wind loads on the blind panels. On the other hand, the vertical distribution of wind pressure coefficients on the panel's interior surface is almost uniform in the permeable panel case, which validates the wind tunnel technique.

In Chapter 6, the wind force coefficients on the blind panels are investigated in more detail. The peak wind force coefficients on the panel ranges approximately +4 to -4 regardless the porosity. The results indicate that the wind pressure coefficients on the rooftop near the blind panel can be used for estimating the net wind forces on the panel except for the solid panel case. In addition, the mechanism producing large positive pressure coefficients on the interior surface of solid blind panel is discussed based on the visualization of the local flow around the blind panel.

Chapter 7 summarizes the main conclusions obtained from the present study. 